\title{
Willingness to Pay for Premium Tourism Services:
}

\author{
A Case of Labuan Bajo, Indonesia
}

\author{
Jappy P. Fanggidae*, Patrisius Seran \\ Business Administration Department \\ State Polytechnic of Kupang \\ Kupang, Indonesia \\ *jappy.fanggidae@pnk.ac.id, seranpatrisius@gmail.com
}

\begin{abstract}
This study aims at investigating the antecedents of willingness to pay for premium price in tourism context. The object of the study is Labuan Bajo, a well-known tourist destination in Indonesia which is targeted as a premium class destination by the government. Data were collected through a self-administered survey and analysed with quantitative approach. Findings reveal that willingness to pay premium is influenced by interdependent trait indirectly through ecotourism attitude. This result discloses the role of personality differences in affecting willingness to pay premium tourism. Theoretical and practical contributions of the present study were discussed.
\end{abstract}

Keywords-willingness to pay premium, ecotourism attitude, environment belief, interdependent

\section{INTRODUCTION}

The Indonesian Government through the Ministry of Tourism has set Labuan Bajo as one of the five super-priority tourism areas in Indonesia where the government's attention in the form of physical and non-physical development are focused on [1]. Labuan Bajo which is famous for its nature tourism of the Komodo National Park offers a unique tour to the Komodo island where visitors can see and even interact with this ancient animal in their natural habitat. Labuan Bajo is special because Komodo native habitat only exists in this area of the world. Given this privilege, the central government of Indonesia and the government of Province of East Nusa Tenggara (i.e., local government) have proposed Labuan Bajo as a premium tourism area [2]. In other words, Labuan Bajo will be one of exclusive tourist destinations in Indonesia. Based on this background, the practical question that this study aims to answer is: "Is Labuan Bajo ready to be a premium tourist destination?"

Data on hotel occupancy in Labuan Bajo in recent years can provide an indication of how the tourists' spending in the tourist destination. According to data from the Central Statistics Agency (BPS) of West Manggarai Regency, occupancy rates for star and non-starred hotels experience different trends [3]. In general, during the period of 2014-2018, the number of guests staying at hotels increased sharply, that are 77,275 people in 2014 to 170,081 in 2018 or an increase of more than $100 \%$ over 4 years. However, if examined further, this rapid increase only occurred in non-star hotels only, not in star hotels. In non-starred hotels, occupancy rates increased by $200 \%$, while in starred hotels, the growth in the number of occupancies was $42 \%$ [3].

According to the data abovementioned, the visitors of Labuan Bajo are mostly those who are reluctant to pay five-star hotels during their stay. Paradoxically, the concept of premium tourism is associated with the concept of luxury where visitors are willing to pay to enjoy a unique tourist experience. Premium tourism according to Poelina and Nordensvard [4] is defined as a tourist destination that meets the elements of high quality, hedonism, high prices, uniqueness, personal service, exclusive character, and high creativity. Premium tourism on the one hand provides a lot more value compared to nonpremium tourism but on the other hand demands tourists to pay higher. Thus, premium tourism does not always bring benefits to all visitors since it merely targets only upper class tourists [4].

However, this does not mean that all non-upper-class visitors are not the target marketing of the premium tourist destination. For example, as a tourist destination that carries the theme of ecotourism, or unique natural attractions [2], Premium tourist destinations can be very interesting places to visit for those who believe that ecotourism is important for environmental sustainability [5]. The tourists who uphold this ecotourism view often do not consider economic conditions as a barrier to visiting ecotourism tourist destinations. Previous research discusses the relationship between ecotourism views and the intention to pay premium prices for certain tourism attractions [6]. Nonetheless, a more comprehensive understanding of premium tourism is needed, especially relating to important aspects that may affect the relationship between environmental beliefs and willingness to pay premium tourism. Therefore, this study aims to fill this gap by investigating the roles of environment beliefs, interdependent trait and ecotourism attitude in influencing ecotourism behaviour. 


\section{LITERATURE REVIEW}

\section{A. Ecotourism}

Tourism is one of the fastest growing industries in the world. According to Statista, global tourism recorded revenues of 1.3 trillion US dollars in 2017 or an almost threefold increase in 2000 of 475 million US dollars. It is even believed that one in eleven jobs in the world is related to the tourism industry. However, the progress of tourism on the one hand has a negative effect on the environment, including the damage it creates to living biota, erosion, congestion, pollution and uncontrolled waste production [7]. As a result, a global awareness called ecotourism emerges. Ecotourism is defined as responsible travel to tourist destinations by preserving the environment and the local community and involving education [8]. Historically, the term ecotourism also refers to travel to natural tourist areas that are still untouched by human civilization with the aim of studying, admiring, and enjoying the natural scenery, flora and fauna that are still natural and the culture found in the area [9].

Ecotourism itself requires financial support both in developed or developing countries. Often the governments unable to fulfil all the financial requirements, and need support from other parties. Unfortunately, the private sector in this case are not interested in investing in the ecotourism sector because there are no prospective incentives even though they are actually financially able to do so [8]. Preliminary research has successfully shown that the ecotourism sector can be supported by those who are willing to pay more than usual during their visits in the tourism area that offer ecotourism attractions. These tourists, called ecotourists, are characterized as those who are relatively willing to spend a lot of money in tourist areas and are likely to have higher incomes than the average of other tourists [6].

\section{B. Environmental Belief, Ecotourism Attitude and Willingness to Pay Premium}

Kilbourne and Pickett [10] explain the definition of environmental belief in two categories, namely general and special definitions. In general, environmental belief is the relationship between humans and the environment which refers to the traditional wisdom of nature. While specifically, environmental belief is a concern for environmental problems such as lack of clean water, depletion of the ozone layer and global warming. Previous research has revealed that people who have a high environmental belief tend to have a more positive attitude toward ecotourism than those who have a low environmental belief [6]. This is explained by the planned behaviour theory which says that attitudes towards a certain value can influence interest in actualizing behaviour [11]

Environmental belief can trigger people to have a positive attitude towards the ecotourism industry. Theoretically, this refers to the mechanism by which a person's belief in everything forms norms or values that guide the attitude [11]. One's strong environmental beliefs will increase attitudes towards ecotourism which subsequently increase the desire to play an active role in protecting the environment [10]. One of the positive behaviours is consuming goods that related to the environment issues even though the price is relatively expensive [6].

\section{Self-Constural in the Relationship between Environmental Beliefs And Attitudes Towards Ecotourism}

Self-construal refers to the way a person sees himself in a fundamental level, whether he considers himself in many separate aspects or connected with others [12]. Self-construal divides humans into two types, namely interdependent and independent self-construal where the difference between the two lies in the difference in the cognitive representation of the self in relation to others. People who have an interdependent view see their relationship with others, their social role in society and the membership of social groups as important. Whereas people who have independent views, on the other hand, are concerned with personality, abilities, values and personal attitudes in their lives [13]. Thus, independent people are considered more separated from the community and the environment compared to interdependent people. Those with an interdependent view also have a higher tendency than independent people in terms of providing support to others who experience problems [14]

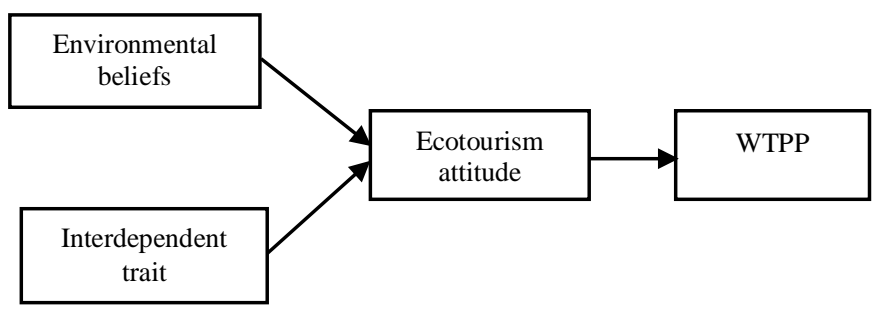

Fig. 1. The research model

Based on the distinctions between independent and interdependent, both are considered to have differences in terms of ecotourism. Since independent people feel separated from the environment and others, independent people are not very responsive to environmental issues, including ecotourism. In contrast, interdependent people are more concern for others and the environment which encourage them to respond more positively to the issue of ecotourism. Based on the review of the literature, it is predicted that both interdependent personality and environmental beliefs influence willingness to pay premium through ecotourism attitude. The research model is illustrated in the Figure 1.

\section{METHODS}

\section{A. Samples and Data Collection}

Respondents in this study were tourists, both foreign and local tourist. Respondents must meet several criteria, which are adults, willing without coercion to fill out questionnaires, already have experience in traveling in Labuan Bajo, and do not aware of the hypothesis of this study. These requirements 
are necessary to eliminate biased answers. Respondents were not rewarded for participating, and they were informed that at any time they could stop filling in if they decided to do so.

The respondents were approached by the research team in several places in Labuan Bajo and Kupang. They were politely asked to fill out a questionnaire. The respondents were informed that the purpose of this research was to find out the readiness of Labuan Bajo as one of the premium tourist destinations from the tourists' perspective.

\section{B. Measures}

The questions in the questionnaire were adapted from previous studies that had passed validation and reliability tests. For the environmental belief variable, the measurement scale was adapted from previous research conducted by Kilbourne and Pickett [10]. The scale of measuring attitudes towards ecotourism and willingness to pay for premium tourism is adapted from a prior study [6]. Meanwhile, for the interdependent variable obtained from research conducted by Singelis [15]. All variables were measured using a 7-point Likert scale.

\section{Analysis Technique}

Since this research aims to find out the relationship between one variable with another variable, the analysis tool used is Structural Equation Modelling (SEM). SmartPLS 3 software was used to simplify SEM calculations. The stages of the analysis itself will be divided into initial and advanced analysis stages. Preliminary analysis is carried out to ensure that all measurement scales are valid and reliable. Whereas further analysis was conducted basically to test the constructed hypothesis.

\section{RESULTS}

\section{A. Measurement Model}

Prior to examining the hypothesis, the reliability and validity of the constructs were inspected. First, to examine for their reliability, we inspected the composite reliability and the Cronbach alpha value. As seen in Table 1, the values of alpha and composite reliability are greater than the threshold [16]. Second, the results showed that the variables were in sufficient levels of validity as shown in Table 1 [17]. The AVE values of the constructs exceeded the expected value of 0.50 , indicating sufficient level of convergent validity.

TABLE I. DESCRIPTIVE STATISTICS.

\begin{tabular}{|l|c|c|c|}
\hline Constructs & Alpha & $\begin{array}{c}\text { Composite } \\
\text { Reliability }\end{array}$ & AVE \\
\hline Environmental beliefs & .82 & .87 & .64 \\
\hline Interdependent & .84 & .89 & .63 \\
\hline Ecotourism attitude & .86 & .89 & .64 \\
\hline WTTP & .75 & .86 & .67 \\
\hline
\end{tabular}

The multicollinearity issues were examined through Variance Inflation Factor (VIF) values. The results exhibited that all VIF values of all indicators were below 5 as the recommended threshold [18].

\section{B. Hypothesis Testing}

The research model is analysed from two directions, either environmental belief or interdependent trait act as the independent variable, ecotourism attitude as the mediator and willingness to pay premium (WTPP) as the dependent variable. First, the model, environmental belief $\rightarrow$ ecotourism attitude $\rightarrow$ WTPP was tested with a mediation analysis using bootstrap technique with 5,000 resamples. The results showed that environmental belief positively affected ecotourism attitude $(\beta$ $=.13, \mathrm{t}=2.34)$, indicating that when the tourists believe that the environmental issues are important, their attitude support the ecotourism. Later, ecotourism attitude positively influenced WTPP $(\beta=.13, t=2.34)$. The environmental belief has a direct and positive effect on WTPP $(\beta=.20, t=2.65)$. However, the indirect effect of environmental belief on WTPP via ecotourism attitude was not significant $(\beta=.07, \mathrm{t}=.88)$.

Second, interdependent $\rightarrow$ ecotourism attitude $\rightarrow$ WTPP was tested with a mediation analysis using bootstrap technique (5,000 resamples). As predicted, interdependent affected ecotourism attitude positively $(\beta=.34, \mathrm{t}=4.38)$, meaning that high interdependent people have more ecotourism attitude than low interdependent people. However, interdependent did not affect WTPP directly $(\beta=-.09, \mathrm{t}=1.21)$. More importantly, interdependent indirectly affected WTPP through ecotourism attitude $(\beta=.07, \mathrm{t}=2.24)$

\section{DISCUSSION}

This research confirms the mediating role of ecotourism attitude in the relationship between interdependent train and willingness to pay premium in Labuan Bajo as a tourist destination. Moreover, this theoretical contribution is novel since it presents a personality trait as a predictor of willingness to pay premium tourism. Thus, policy makers can provide reliable estimates of the abilities and desires of ecotourism tourists to spend their monetary resources while they are in the premium tourist destinations. Considering the importance of interdependent trait in affecting willingness to pay premium in premium tourist destinations, the tourism marketer may include interdependent content in their marketing campaign.

Despite its contributions, this study holds several limitations. First, this study did not include independent trait, the opposite of interdependent trait in the analysis. As these two concepts are closely related each other, it is important to include the two altogether in a future study. It is possible that people low in independent trait also have a tendency to increase their ecotourism attitude and subsequently have higher willingness to pay premium tourism. Second, the data were collected during the Covid-19 pandemic time where tourism is one of the most heavily affected sectors. It is possible then that the respondents were influenced by the condition. Future 
studies may collect data during the normal or new normal conditions and find interesting insight. For example, price sensitivity [5] may not be a determining factor in normal time since people already hold their desire to vacate for quite a long time. Under this condition, it is possible that personality differences are no longer related to willingness to pay premium tourism.

\section{CONCLUSION}

Findings reveal that willingness to pay premium is influenced by interdependent trait indirectly through ecotourism attitude. This result discloses the role of personality differences in affecting willingness to pay premium tourism.

\section{REFERENCES}

[1] Y.G. Wijaya, Menengok Kesiapan 5 Destinasi Wisata Super Prioritas di Indonesia [Online]. Retrieved from: https://travel.kompas.com/read/2019/09/12/150000427/menengokkesiapan-5-destinasi-wisata-super-prioritas-di-indonesia?page=all, Accessed on 13 February 2020.

[2] N. Lumanauw, Tahun 2020, Labuan Bajo Jadi Destinasi Wisata Premium. Berita Satu, 2019.

[3] BPS, Statistik Perhotelan Kabupaten Manggarai Barat 2018: BPS Kabupaten Manggarai Barat [Online]. Retrieved from: https://manggaraibaratkab.bps.go.id/publication.html. Accessed on 13 February 2020.

[4] A. Poelina and J. Nordensvard, "Sustainable luxury tourism, indigenous communities and governance," Sustainable luxury, entrepreneurship, and innovation, Springer, pp. 147-166, 2018.

[5] A. Kazeminia, M. Hultman and R. Mostaghel, "Why pay more for sustainable services? The case of ecotourism," Journal of Business Research, vol. 69, no. 11, pp. 4992-4997, 2016.

[6] M. Hultman, A. Kazeminia and V. Ghasemi, "Intention to visit and willingness to pay premium for ecotourism: The impact of attitude, materialism, and motivation," Journal of Business Research, vol. 68, no. 9, pp. 1854-1861, 2015.

[7] K.L. Andereck, K.M. Valentine, R.C. Knopf and C.A. Vogt, "Residents' perceptions of community tourism impacts," Annals of tourism research, vol. 32, no. 4, pp. 1056-1076, 2005.

[8] M. Meleddu and M. Pulina, "Evaluation of individuals' intention to pay a premium price for ecotourism: An exploratory study," Journal of Behavioral and Experimental Economics, vol. 65, pp. 67-78, 2016.

[9] H.M. Donohoe and R.D. Needham, "Ecotourism: The evolving contemporary definition," Journal of Ecotourism, vol. 5, no. 3, pp. 192210, 2006.

[10] W. Kilbourne and G. Pickett, "How materialism affects environmental beliefs, concern, and environmentally responsible behavior," Journal of Business Research, vol. 61, no. 9, pp. 885-893, 2008.

[11] I. Ajzen, "The theory of planned behavior," Organizational behavior and human decision, vol. 50, no. 2, pp. 179-211, 1991.

[12] H.R. Markus and S. Kitayama, "Culture and the self: Implications for cognition, emotion, and motivation," Psychological review, vol. 98, no. 2, p. 224, 1991.

[13] J.Y. Seo and D.L. Scammon, "Does feeling holier than others predict good deeds? Self-construal, self-enhancement and helping behavior," Journal of Consumer Marketing, 2014.

[14] R.B. Van Baaren, T.G. Horgan, T.L. Chartrand and M. Dijkmans, "The forest, the trees, and the chameleon: Context dependence and mimicry," Journal of Personality and Social Psychology, vol. 86, no. 3, p. 453, 2004.

[15] T.M. Singelis, "The measurement of independent and interdependent self-construals," Personality and social psychology bulletin, vol. 20, no. 5, pp. 580-591, 1994.

[16] W.W. Chin, "The partial least squares approach to structural equation modeling," Modern methods for business research, vol. 295, no. 2, pp. 295-336, 1998.

[17] P.R. Hinton, I. McMurray and C. Brownlow, SPSS explained. Routledge, 2014.

[18] A. Diamantopoulos and H.M. Winklhofer, "Index construction with formative indicators: An alternative to scale development," Journal of marketing research, vol. 38, no. 2, pp. 269-277, 2001. 